\title{
Commercialising Public Research under the Open Innovation Model: New Trends*
}

\author{
Mario Cervantes, Dirk Meissner
}

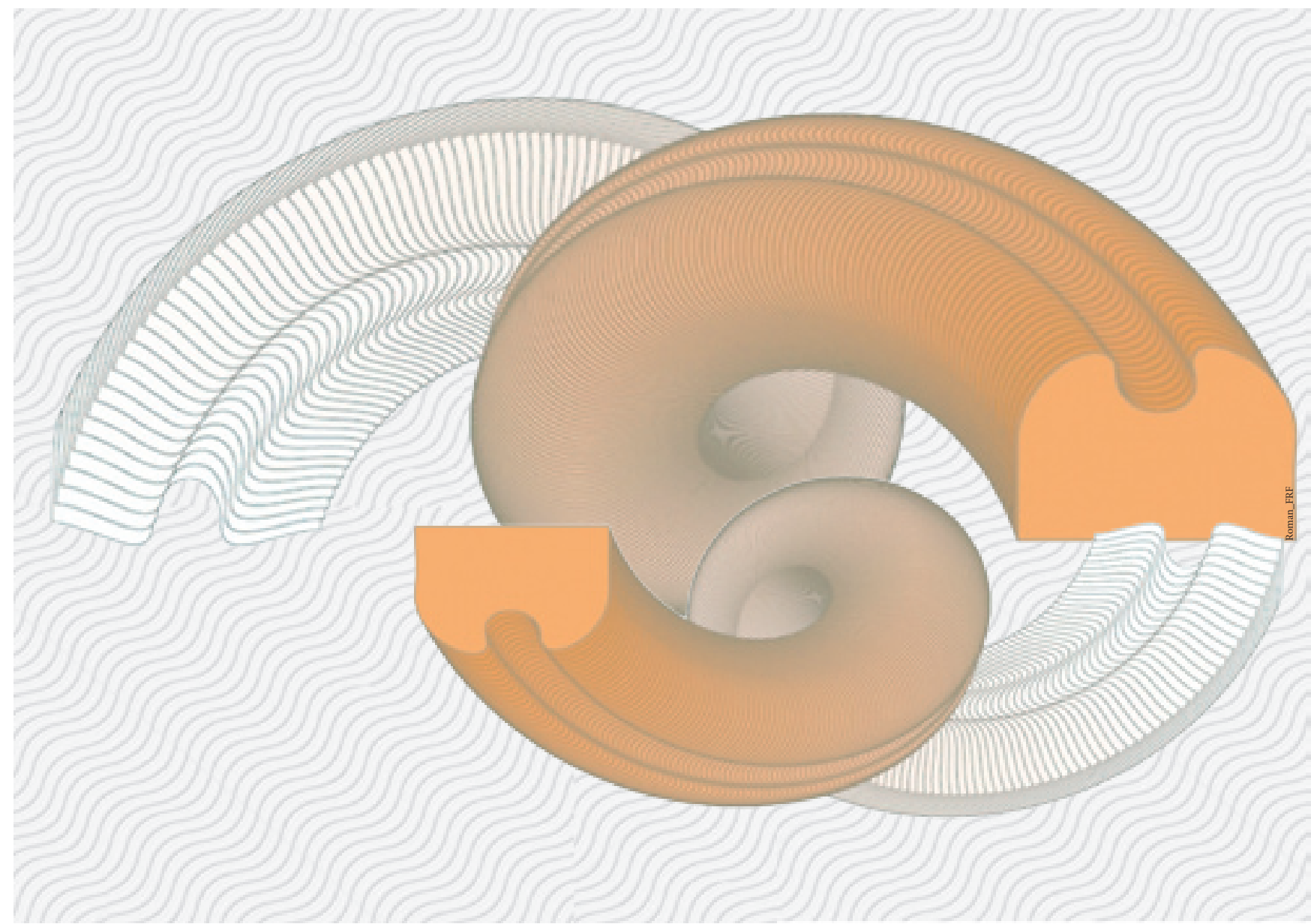

Being influenced by increasingly heightened global competition, companies are entering into partnerships with other companies, universities or public research institutions (PRIs) to leverage external competences to foster innovation. The search for partners and the management of cooperation itself are new challenges especially in terms of administering intellectual property rights.

The paper highlights recent trends related to knowledge and technology transfer from public research and education to industry. It considers legislative initiatives to target industry engagement, new technology transfer office models, collaborative intellectual property (IP) tools, and initiatives to facilitate access to public research results.
Mario Cervantes - Senior Economist, Country Studies and Outlook Division, OECD Directorate for Science, Technology and Industry. Address: 2, rue André Pascal 75775 Paris Cedex 16 France. E-mail: mario.cervantes@oecd.org

Dirk Meissner - Deputy Head, Research Laboratory for Science and Technology Studies, Institute for Statistical Studies and Economics of Knowledge, National Research University - Higher School of Economics. Address: 11, Myasnitskaya str., Moscow 101000, Russian Federation.E-mail: dmeissner@hse.ru

\section{Keywords}

open innovation; technology transfer; commercialisation; public research institutes; universities; industry; co-operation

Citation: Cervantes M., Meissner D. (2014) Commercialising Public Research under the Open Innovation Model: New Trends. Foresight-Russia, vol. 8 , no 3, pp. 70-81.

\footnotetext{
* Support from the Basic Research Program of the National Research University - Higher School of Economics is gratefully acknowledged.

The paper partially draws on cross-country comparative analysis of public research commercialisation practices [Cervantes et al., 2014].
} 
$\mathrm{R}$ ecent years have witnessed intensified discussion on the role and function of actors in the Triple Helix Concept, sometimes also referred to as the Knowledge Triangle. This concept pays particular attention to the role of universities (also referred to as Higher Education Institutes - HEI) and Public Research Institutes (PRI) and their contribution to innovation. Against the widespread belief that knowledge and technology transfer activities might impact the academic work of scientists several studies found evidence that the engagement of scientists in technology transfer and commercialization activities does not have negative impacts on the quality and quantity of scientists' academic work. On the contrary, studies show that scientists who are actively engaged in technology and knowledge transfer, i.e. through patenting, also enjoy a high scientific reputation and in most cases do excellent scientific work [Van Looy et al., 2006; Carayol, 2007; Calderini, Franzoni, 2004; Breschi et al., 2006]. Evidence shows that post-invention, researchers' publication activity actually increases. Thus there does not seem to be a fundamental incompatibility between engaging in knowledge and technology transfer and producing new scientific knowledge.

There is also no clear evidence that patenting by researchers shifts the focus of research toward more applied work. Indeed, some evidence suggests researchers' patenting activity has strong positive effects on subsequent publication output as well as on their citation records [Buenstorf, 2009]. In engineering disciplines, high-profile scientists accounted for most of the academic patenting activity [Meyer, 2006]; Fukugawa shows that the quality of research staff has a strong influence on knowledge and technology transfer [Fukugawa, 2009]. Firms that undertook $\mathrm{R} \& \mathrm{D}$ on a continuous basis were more likely to have linkages with knowledge providers (HEIs and PRIs) [Tether, Tajar, 2008]. This implies that such links tend to complement rather than substitute the firm's own innovation activities, an idea expressed in the Open Innovation Model [Chesbrough, 2006].

In addition, there appears to be a positive relationship between using specialist knowledge providers and the level of the company's investment in innovation. A firm's expenditure on innovation is positively associated with the use of consultants and collaboration with private research organizations, but only slightly associated with using the public research sector [Tether, Tajar, 2008]. The weaker involvement with public sector research contrasts with the strong links between firm and consultants (and to a lesser extent private research organizations). The geographic focus of the company is another important dimension: companies with an international outlook have significantly more and stronger links with private and public research organizations than domestically oriented firms.

A challenging innovative business environment brings new problems to the surface, putting firms incapable of entering a new era on the edge while giving a chance for the most flexible companies to seize the new opportunities [Nayyar, 2006, Teece, 2007]. Inter alia, emerging new technologies arise and continue to show significant spillover effects on all areas of the economy, fostering the search for new forms of innovation activity [Meissner, 2012]. Consequently, it is assumed that HEIs and PRIs can lead innovation activities and wider collaboration based on their expanded networks. Accordingly, the complexity of knowledge and technologies increases and equally importantly, their availability and place of origin becomes more diverse. Thus the commercialization of public research is a major goal of national science and technology policies and a key function of HEI and PRIs, alongside teaching, education and knowledge dissemination.

Public research has been the source of many of today's innovations, sometimes as a by-product of basic research and sometimes without any prospect of a direct business application. Well-known examples are the techniques of recombinant DNA, the global positioning system (GPS), MP3 technology and 
Siri, Apple's voice recognition technology. Data on scientific sources of many of today's nanotechnology, ICT and biotechnology patents provide additional evidence of the linkages between technological innovations and public research [OECD, 2013a].

Knowledge and research generated by the public research system diffuses through a variety of channels, including mobility of academic staff, scientific publications, conferences, contract research with industry, and licensing of university inventions. Nevertheless, much policy attention in OECD countries has centred on promoting knowledge transfer and spillovers through publications, the patenting and licensing of academic inventions, and the promotion of academic start-ups. More recently, these channels have been complemented by publicprivate partnerships, open science initiatives and entrepreneurial channels, such as student-based start-ups and related financing and mobility schemes. In the United States, for example, start-ups created by university graduates are more numerous and more dynamic than those founded by faculty and researchers.

The rationale for public support for commercialization has its roots in market and system failures. Weak commercialization of public research may have several sources [Meissner, Zaichenko, 2012]:

- asymmetric information, as potential users may not be aware of university inventions;

- risk or non-appropriability of the results of public R\&D because ownership of university inventions may not be clear enough for industrial partners to engage in commercialization;

- demand for research may be weak as companies, especially SMEs, may not carry out their own R\&D;

- coordination problems among R\&D participants as firms' and universities' incentives may be misaligned because of their different missions;

- lack of finance for developing prototypes and demonstration projects that would help attract private finance for commercializing academic inventions.

A recent OECD report on new trends and strategies for the transfer, exploitation and commercialization of public research shows that this area has undergone much change and experimentation in recent years [OECD, 2013b]. There is evidence of a levelling off in key performance indicators of PRIs, such as academic patenting. At the same time, governments as well as universities and PRIs are seeking new strategies and approaches that can boost the effectiveness of PRIs in providing better services to fulfil their missions, one of which is engagement in commercialization activities which are increasingly requested by companies under the open innovation paradigm.

\section{Managing innovation under the «open innovation model»}

The basic principles of the innovation management process have not changed considerably over the last decades. What has changed and continues to change is the role and meaning of different sources of innovation and the increasing importance of some exploitation paths. At the same time, shareholders' expectations regarding companies overall performance have continued to increase. Their expectations now reflect a better understanding that innovation increases the value of their investment in the short and long term and that innovation is more than R\&D. The management of interfaces - both company internal interfaces between different departments and functions but also interfaces to external organizations - becomes crucial. Doing so means that the company can screen and use external sources and capacities that are complementary to, and in some cases substitute, its existing internal competencies. As a consequence, 
innovative firms have to learn how to manage even more complex business processes, adapting solutions to the nature of markets and technological know-how (Table 1).

Traditional innovation management processes used to put special emphasis on $\mathrm{R} \& \mathrm{D}$ as the most important determinant of technology-based non-price competitiveness. Although different sources of innovation such as benchmarking with competitors, customer orientation and, to some extent, collaboration with suppliers, competitors and the public research base were recognised as useful, the management of the interfaces with these sources of complementary competences was not stressed a strategic objective. Within the 'open innovation paradigm', managing innovation now emphasises more strongly outputs regardless of the origin of the inputs to the innovation. It aims to efficiently generate and use knowledge and competences required to make new or improved solutions to solve known or unknown problems, and/or new ways to better satisfy needs. This includes products, processes and services traded on markets or delivered through non-commercial channels. In sum, innovation management is now about optimising all aspects of innovation processes and also providing the framework conditions (both in and outside the organization) conducive to innovation.

The widespread emergence of open innovation management approaches in companies offers PRIs and HEIs new roles and greater opportunities. Spillovers in different shapes are becoming ever more important when it comes to the generation of innovation. However a few critical issues need a closer look when discussing the potential contribution of the public research base to company innovation. First, it needs to be mentioned that the absorptive capacity of companies is crucial for open innovation. Second, public research has in principle other missions and duties to fulfil beyond innovation broadly defined. Third a key challenge for companies is identifying relevant new ideas developed externally, encouraging their creation and gaining access to them. Whilst some of these external ideas can be found and accessed without forging relationships (e.g. through the internet or social media platforms), it is more of ten the case that some form of interaction will occur such that both parties are aware of their involvement. Thus, rather than remotely recognising, reading and using knowledge produced by the science base, firms following open innovation strategies are more inclined to forge relationships with key scientists or research groups in the public science base, and to influence the work that they undertake. Companies hence recognise and understand potentially valuable knowledge outside the firm, assimilating valuable new knowledge through transformative learning and using the assimilated knowledge to create new knowledge and commercial outputs through exploitative learning.

\begin{tabular}{|c|c|c|c|c|}
\hline \multirow{4}{*}{ Markets } & \multirow{2}{*}{$\begin{array}{l}\text { Unfamiliar } \\
\text { Non-core }\end{array}$} & $\begin{array}{l}\text { Joint venture } \\
\text { Contract R\&D }\end{array}$ & $\begin{array}{l}\text { Venture capital } \\
\text { Internal venture fund }\end{array}$ & $\begin{array}{l}\text { Spin-off } \\
\text { Sell }\end{array}$ \\
\hline & & $\begin{array}{l}\text { Joint development } \\
\text { Acquisition }\end{array}$ & $\begin{array}{l}\text { Licensing } \\
\text { Equity stake }\end{array}$ & $\begin{array}{c}\text { Venture capital } \\
\text { Internal venture fund }\end{array}$ \\
\hline & \multirow[t]{2}{*}{ Core } & $\begin{array}{l}\text { Acquisition } \\
\text { Internal development }\end{array}$ & $\begin{array}{c}\text { Internal development } \\
\text { Licensing } \\
\text { Acquisition }\end{array}$ & $\begin{array}{l}\text { Joint venture } \\
\text { Contract R\&D }\end{array}$ \\
\hline & & Core & $\begin{array}{l}\text { Non-core } \\
\text { Technology }\end{array}$ & Unfamiliar \\
\hline
\end{tabular}


Since its inception, open innovation has become common practice among innovative companies. Building on the basic principles of open innovation, there are three major types of open innovation: 1) inside-out, 2) outside-in and 3) the totally open model. The inside-out model is relevant for only a few companies and is usually the exception not the rule. Companies following this model aim to increase their revenues by spinning out non-core in-house technology to the market. Outward licensing to partners reflects mostly opportunistic activities by global companies due to limited potential for developing the technology internally. Outward licensing is to both small and big companies. Companies following an outside-in model make use of a broad range of competences and sources for their innovation activities. Customers are the most relevant and increasingly important source of ideas. Often the focus is on lead users. Customers are also becoming more involved in the financing of innovation. There are some limitations since it is not always possible to define emerging needs. Universities and public research institutions are an important source for companies when it comes to hiring qualified staff and obtaining know-how; here $\mathrm{PhD}$ programmes and new hires are particularly important. Most companies focus on a small number of links, but of high quality, to specific universities or individual professors. Start-ups, consultants, and engineering firms are a less important source for innovators and are only screened opportunistically. Rarely do global players approach start-ups, consultants, and engineering firms directly so it is up to the latter to approach the big companies. Suppliers are gaining in importance as a source for innovation since they usually possess specialised capabilities in materials and $\mathrm{R} \& \mathrm{D}$.

In a totally open model, companies systematically apply the inside-out und outside-in model and expand that towards competitors (i.e. coopetition). Coopetition, the combination of cooperation and competition, is used in precompetitive research, to create a new market, to share costs and risks or to set industry standards.

New research shows that companies' absorptive capacity is a crucial precondition for open innovation. Based on the expected role of scientific knowledge in the search process for innovation, as well as in creating innovations, and the inherent importance of externally generated scientific knowledge, it follows that firms enjoying enhanced access to university-generated scientific knowledge will demonstrate greater success in searching for new inventions [Fabrizio, 2009]. His analysis shows that patents in technology fields characterised by rapid advance will cite more recent prior art, e.g. scientific publications. In contrast, technology fields characterised by fast follow-on innovation and relatively rapid obsolescence of the knowledge base are characterised by quickly peaking distributions of backward citation lags with relatively low average backward citation lags. Patents relying on relatively older technology as patented prior art are characterised by a less peaky distribution with a higher average citation lag. It follows that the absorptive capacity of companies, expressed in terms of a company's internal capacity for basic research, has a significant impact on the uptake of state of the art and emerging scientific knowledge.

\section{Responding to open innovation: commercialization approaches at PRIs and universities}

\section{Patent applications, licensing income and spin-offs as indicators of commercialization}

Patents, licensing income and spin-offs are frequently used indicators to assess an institution's or a country's capabilities to turn public research into innovation. In terms of patent applications filed by universities in the US, the average annual growth rate fell from $11.8 \%$ (between 2001 and 2005) to 1.3\% (2006-2010). PRIs experienced a negative growth of $-1.3 \%$ over the latter period, compared 
Figure 1. Licensing income (as a percentage of R\&D expenditures)

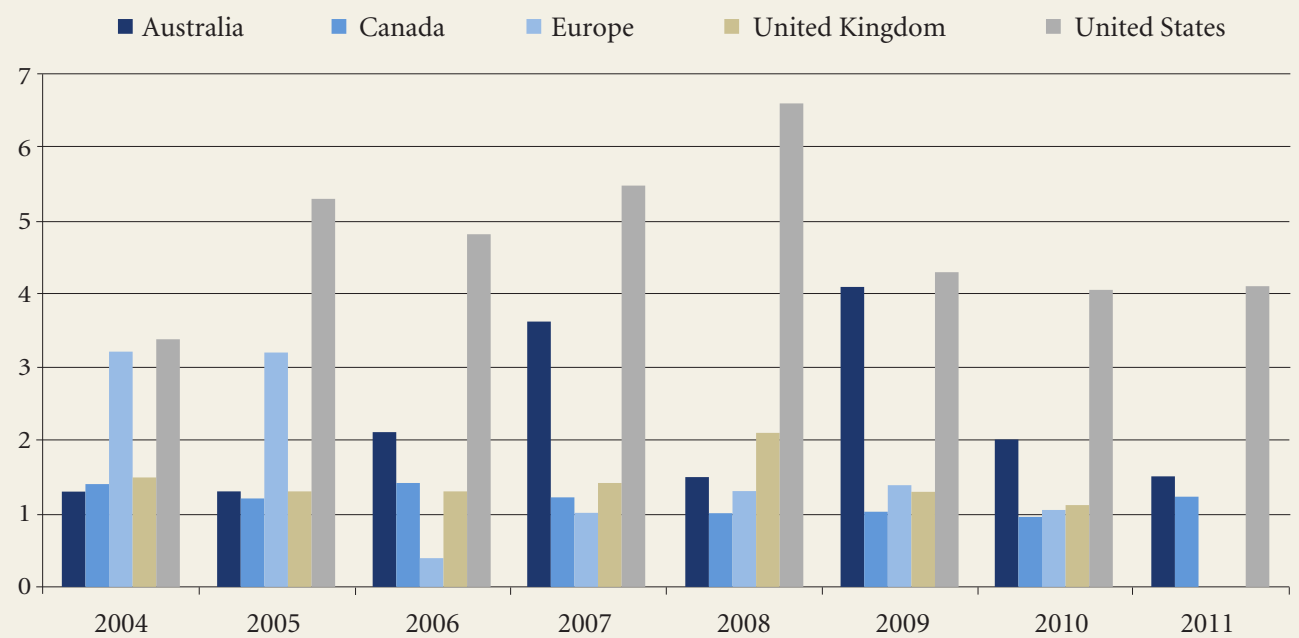

Source: Authors' calculations based on data from Department of Innovation, Industry, Science and Research (DIISR) [DIISR, 2011, 2012]; European Commission [European Commission, 2012]; US and Canadian Associations of University Technology Managers (AUTM) [AUTM, 2009a, 2009b, 2010a, 2010b, 2011a, 2011b, 2012a, 2012b] ; Higher Education Funding Council for England (HEFCE) [HEFCE, $2009,2010,2011,2012]$

to $5.3 \%$ growth between 2001 and 2005. Data on invention disclosures (the first of ficial recording of an academic invention, measured as number of disclosures per USD 100 million of R\&D expenditures) show a slight drop on average from 2004-2007 to 2008-2011.

Numbers of university spin-offs have not significantly expanded either despite continued policy support in the United States. In the US, four spin-offs are created on average per year in one university ${ }^{1}$. The number of spin-off companies formed per USD 100 million of research expenditures fell on average in 2008 in large OECD countries, while the ratio stabilised in 2009-2011 to pre-2008 levels.

On the other hand, licensing income as a percentage of research expenditures has remained relatively stable in selected OECD countries and regions (Figure 1). Moreover, only a small number of universities account for the bulk of total licensing income. In Europe, 10\% of universities accounted for approximately $85 \%$ of total licensing income.

While patents, licenses and spin-offs remain important channels for commercializing public research, other channels such as collaborative research (e.g. public-private partnerships), student and research staff mobility, as well as contract research and research staff consulting appear to be becoming more important; however, solid data are lacking. Evidence from the United States shows that recent graduates are twice as likely as the academic staff to create a business venture the graduates' spin-offs are also of the same quality [Åstebro et al., 2012]. Similar results come from an analysis of Academic Enterprise Europe Awards finalists: the largest group of founders were doctoral students $38 \%$ of the 28 founders interviewed) [Hoefer et al., 2013].

In addition, technological progress is transforming some of the traditional channels, especially those dependent on repeated personal contact and exchange of information. Virtual networks enable greater collaboration between researchers and industry in the exchange and sale of IP. Open access journals provide a complementary channel for diffusing scientific results, while open research data initiatives that make research available for further investigation or innovation represent a new knowledge transfer channel. 
As a result of the importance of other channels and to better account for the impact of public research, universities and PRIs are now trying to devise new metrics and indicators: for example, student employment in funded projects, alumni in the workforce, services to external clients, and inter-sectoral mobility of doctoral holders.

\section{Encouraging industry engagement by granting licenses on IP rights free of charge}

One approach in promoting the commercialization of public research involves universities exchanging knowledge embedded in IP documents and contracts, particularly with industry. Industry-science relationships concerning IP rights have reached a critical point. Evidence suggests that universities pursue their IP negotiations with firms more aggressively than in the past.

The major issue of contention is on the value and income from IP and on overcoming the different perceptions of industry and universities. The University of Glasgow, for example, introduced the Easy Access Programme in 2010 to provide free access to university inventions on a royalty-free and fee-free basis. In March 2011, the UK Intellectual Property Office backed a proposal from the universities of Glasgow, Bristol and King's College London to develop a consortium of universities into the Easy Access Innovation Partnership. The University of New South Wales in Australia and CERN (European Organization for Nuclear Research), a major inter-governmental research facility, have also adopted versions of the Easy Access IP framework.

\section{Legislative and administrative procedures targeting research and teaching personnel}

As HEIs have some leeway with regard to national IP regulations and can develop their own, internal IP regulations and processes, some have experimented with alternate approaches. For example, some have decided to provide preferential treatment to academic staff and lecturers wishing to license the technologies they developed. Other HEIs allow their staff to establish new ventures, granting leaves of absence, or allow 'tenure clock stoppage' for academic staff, so that they can pursue commercialization activities. Some universities are considering taking into account the commercial track record of their academic staff when deciding on promotions to permanent positions (tenure).

HEIs in OECD countries increasingly face the issue of ownership of IP created by graduate students and other non-research or teaching staff who are engaged in R\&D. In OECD member countries, graduate students and PhD holders account for a growing share of non-research or teaching staff carrying out R\&D in universities. Owing to these changes and to avoid IP disputes between students and universities, the University of Missouri in the US established a policy in 2011 that generally allows students to own any invention made during their enrollment.

Mobility of researchers is an important channel for the circulation of knowledge. Programmes such as Belgium's 'Doctoris' programme and France's industrial agreements for training through research (Conventions Industrielles de Formation par la REcherche, CIFRE) are two examples of policies to foster mobility and the development of competences of doctoral students.

\section{New forms and models of technology transfer offices}

Increasing numbers of universities, PRIs as well as governments (of all levels) have discussed steps to invest or experiment with new intermediation structures. Most of these discussions centred on replacing or improving technology transfer office (TTO) structures and services, including but not limited to Technology Transfer Alliances (TTAs), internet-based models, for-profit models or ap- 
proaches to vest some rights with inventors while maintaining university ownership (e.g. the Free Agency model).

Given the limited ability of mid-sized universities to generate enough income to cover expenses of their TTOs, some proponents argue that it may be more efficient to share services in the form of TTAs. In France, the French National Research Agency (Agence Nationale de la Recherche, ANR) has established a fund to create Technological Transfer Acceleration Companies (Sociétés d'Accélération de Transfert de Technologies, SATT) to reduce fragmentation of technology transfer services at the regional level. These companies are mainly owned by a consortium of universities and PRIs, and will assist in proof-ofconcept funding and IP commercialization. To date, 11 such companies have been created across France.

Some HEIs have turned to or established privately funded TTOs for cost or efficiency reasons. These are institutionalized in the form of limited liability corporations. The rationale is that private agents might be better positioned to commercialize university inventions. In Israel the majority of TTOs operate under a limited liability model, partly or wholly owned by universities. In addition to a traditional TTO, Stanford University has established a separate whollyowned limited liability corporation (Stanford OTL-LLC) to allow Stanford's TTO to act as a licensing agent for other universities.

Advances in ICTs have also permitted mechanisms that complement existing internal TTO structures through Internet-based platforms. The France Technology Transfer (FTT) platform, created by the French TTO association and the French National Innovation Financing Agency (OSEO), has been established to better showcase technologies developed by French universities and PRIs to the corporate sector.

Discussions in the US suggest a new model of vesting ownership with inventors but maintaining university ownership. In this case, researchers would be given the choice between their university TTO or an agent elsewhere (i.e. Free Agency model). However, many academics and practitioners question the usefulness of such an approach. Concerns include, among others, the limitations of adjusting TTO performance through competition, the potential capacity constraints of external university TTOs, regional and local economic development issues, overlapping interests and unclear payout schemes.

\section{Collaborative IP tools}

Some OECD countries have started to sponsor the creation of patent funds specifically for PRIs, either directly or through state-owned banks, which fund the acquisition of patent rights among other activities. Patent funds with a focus on PRI-generated patents have been implemented in France (France Brevets), Japan (the Life Sciences IP Platform Fund) and Korea (IP Cube Partners).

A large share of HEI and PRI patents remains commercially unexploited; neither licensed nor used internally, nor held for purely defensive purposes. Allowing preferential access to unexploited patents is one way of addressing the issue of 'sleeping patents'. The French National Centre for Scientific Research (Centre National de la Recherche Scientifique, CNRS) has established a programme called 'PR2 - Enhanced Partnership SME Research Programme', in which patents will be offered to SMEs on favourable terms.

The creation of standard licensing agreements has also become a popular instrument among HEIs and PRIs. For example, the United Kingdom draws up licensing agreements using the 'Lambert Toolkit'; Germany has model R\&D co-operative agreements; 'Schlüter' model agreements exist in Denmark; and DESCA model consortium agreements are used in the European Commission's (EC) FP7 projects to address industry claims of difficulties in negotiating li- 
cence agreements with PRIs. Licensing agreements of ten involve 'model' technology cooperation agreements that limit the potential of IP-related conflicts and disputes.

\section{Facilitating access to public research results}

Access to public R\&D results has become a key issue, reflecting increasing interest in improving the accessibility of scientific research findings in general, and in particular the results of publicly funded research. Institutional and private users of ten have to pay to secure access to this research. Fuelled by advances in ICT technologies, the most common policy instrument is the requirement to publish in digital format. As of 2013, the Canadian Institutes of Health Research (CIHR) mandates in its open access policy that all research papers generated from CIHR-funded projects must be freely accessible through the publisher's website or an online repository within 12 months of publication. New Zealand and Spain also require publication of publicly funded research results in digitised format in an open access repository. The Office of Science and Technology Policy (OSTP) of the White House in the US issued a policy memorandum in early 2013 for federal agencies that spend more than USD 100 million on research to make published research results and digital scientific data more accessible to the wider public.

Open access also requires an enabling infrastructure. The EC has supported the building of repositories and infrastructure through the Framework Programmes for Research and Technological Development. Projects implemented include 'Digital Repository Infrastructure Vision for European Research' (DRIVER), DRIVER II, 'Open Access Infrastructure for Research in Europe' (OpenAIRE), and OpenAIREplus initiatives.

\section{Financing of public research based spin-offs}

The financing of innovation from invention through to commercialization requires long-term capital commitments. New ventures (particularly technologybased public research spin-offs) face the liabilities of newness and smallness, which limit their access to resources such as financial capital.

Many HEIs and PRIs complement government funding for start-ups by setting up their own gap funding schemes, either fully funded or co-funded with institutional resources. Europe has around 73 university- and PRI-oriented gap funding funds. Typically, most gap funding programmes also provide business and advisory services, incubator space, market research and educational training. Examples include the Chalmers Innovation Seed Fund, the Gemma Frisius Fonds KU Leuven, and the Genopole 1er Jour fund.

While venture capital tends to attract most attention from policy makers, there are also additional sources of finance for research and commercialization such as IP collateral-based funding, angel investors, and crowd funding for research. There is an active ongoing debate surrounding the potential of crowd funding to alleviate the financing gap faced by research-based ventures. External corporate venturing activities, such as joint venturing, acquisitions and corporate venture capital (CVC), also constitute a potential source of financial capital and managerial expertise for public research spin-offs. Lastly, spin-offs seeking debt financing may find that their most valuable property for use as collateral is their trademarks, copyrights, patents or prototypes.

\section{Researcher and innovators' soft skills for knowledge and technology transfer}

A case study of Belgian collective research centres found that successfully transferring relevant knowledge and technology to the companies requires a critical level of internal R\&D. Thus it is an absolute necessity to build the company's own absorptive capacity and complement it with external R\&D [Spithoven et al., 
2010]. The level of absorptive capacity also determines the choice of the transfer relationship, e.g. the configuration of the relationship between companies and PRIs [Oerlemans, Knoben, 2010]. Thus, the most significant factor that determines a firm's choice about the relationship configuration is the level of internal resource use along with the scope of a firm's innovative activities. Hence a strong internal resource base allows a firm to be an attractive partner, enabling the firm to successfully utilize knowledge and technology produced by external research organizations.

\section{Scientist profiles}

Several studies show that scientists' engagement in technology transfer by no means has a negative impact on the quality and quantity of their academic work [Shmatko, 2013]. There does not seem to be a fundamental incompatibility between engaging in technology transfer and being academically productive. Inventing commercially valuable technologies comes with increasing research output over and above those associated with academic inventions more generally. Meyer found that, in engineering disciplines in particular, it was the highprofile scientists who tended to engage more in patenting [Meyer, 2006].

\section{Conclusions}

The rise of the open innovation model not only intensifies the internationalization of business $R \& D$. Innovation is more than $R \& D$ and its more open process involves crossing geographical, institutional and disciplinary borders. Led by multinational companies, open innovation now engages all the other actors of innovation systems, including smaller firms, public research organizations, and customers. It challenges market actors, and especially innovators, to be flexible. They must reinvent their business model to survive the increasingly knowledgebased global competition.

However, it challenges government policies even more. Policies of ten have traditional approaches and instruments, which may not be most effective in maximising national benefits from globalised innovation markets and networks. The single most important response should be proactive: promoting all forms of linkages to strengthen national or regional innovation systems, with particular attention paid to SMEs. Another important objective should be to improve the framework conditions for innovation, including appropriate specialised infrastructure (for example, the system of public research) to be able to retain or attract increasingly mobile investments in knowledge and talented people.

Drawing on the open innovation paradigm, a recent OECD analysis of commercialization activities of public research found evidence that many OECD countries are reviewing their institutions and infrastructure that support the networks and markets for transferring and commercializing the results of public research. Traditional approaches and models now face considerable limitations. For example, the narrow focus on research and teaching staff as inventors, the natural/physical sciences and patenting/licensing; the apparent mismatch between the supply and demand of public sector knowledge; harder financing for new ventures; limited evidence and metrics for assessing changes, and a lack of benchmarking institutions and international comparisons. All these are barriers to successful interactions between relevant actors and initiatives at different levels. Given these barriers and ongoing changes in organizational structures, orientations, linkages and other factors, it is important to regularly take stock and understand the changes well. Governmental and institutional support for new models of commercialization will have to ensure - possibly through pilot projects - quality, participation and adequate rewards to all who contribute to the research and commercialization effort. 
Innovative linkages are driven by the supply and demand for technology and knowledge. The existing interfaces for technology transfer are thus contingent on technology supply and demand (technological development) as well as on the framework conditions, and consequently change over time [Kroll, Schiller, 2010]. Systemic thinking on the evolution of innovation may imply that national innovation systems may be characterized by fragmentation and isolation. The main point here is that the of ten quoted domestically anchored co-evolution of actors in an innovation system will only happen if the interfaces of technology transfer are anchored nationally and are thus able to tie together the actors in question. However, such networks among domestic actors do not necessarily form innovative linkages even when actors are located in geographical proximity. Nevertheless, if science and market forces are free to move technology, then the supply of knowledge will match regardless of the geographical dimension. It appears that thinking in terms of national innovation systems is increasingly challenged by an approach towards an idea of networks, which are spread globally but increasingly interconnected. It thus becomes increasingly important for governments to understand the nature and extent of these networks, not least as there is growing concern by governments that academic research be relevant and accessible to industry [Tether, Tajar, 2008]. Traditional analysis of industry-science links usually ignores complementary sources of specialist knowledge such as consultancies and private research institutes. Such knowledge-intensive services (KIBS) are becoming increasingly important in creating and commercializing new products, services and technological processes. Given the structures of most innovation systems, such institutions should not be neglected as they complement the capacities of universities and other public research organizations.

In terms of future research, a relatively unexplored area is the role of current and former students as key actors in the exploitation and possible commercialization of new knowledge, particularly in universities. Acknowledging this role, understanding the driving factors, and the main barriers could prove a particularly fruitful direction for future research. In the same vein, evidence on the effectiveness and impact of financial instruments to support academic entrepreneurs (university seed funds, etc.) could help in the search for new financing mechanisms.

The question of how researchers are incentivized to participate in knowledge transfer and commercialization by their institutional environment could be another interesting avenue for future work. It would be instructive to further analyze informal contacts, consulting and collaborative research as these channels are important for industry. Understanding researchers' involvement in these activities requires knowing more about their mindset, motivations and competences, and the institutional culture and leadership in their workplace. Some evidence of these factors is available, yet future research at the individual and institutional level could improve policy-making.

Åstebro T., Bazzazian N., Braguinsky S. (2012) Startups by recent university graduates and their faculty: Implications for university entrepreneurship policy. Research Policy, vol. 41, pp. 663-677.

AUTM (2009a) Highlights of the AUTM U.S. Licensing Activity Survey: FY2008, Deerfield, IL: Association of University Technology Managers.

AUTM (2009b) Highlights of the AUTM Canadian Licensing Activity Survey: FY2008, Deerfield, IL: Association of University Technology Managers.

AUTM (2010a) Highlights of the AUTM U.S. Licensing Activity Survey: FY2009, Deerfield, IL: Association of University Technology Managers.

AUTM (2010b) Highlights of the AUTM Canadian Licensing Activity Survey: FY2009, Deerfield, IL: Association of University Technology Managers. 
AUTM (2011a) Highlights of the AUTM U.S. Licensing Activity Survey: FY2010, Deerfield, IL: Association of University Technology Managers.

AUTM (2011b) Highlights of the AUTM Canadian Licensing Activity Survey: FY2010, Deerfield, IL: Association of University Technology Managers.

AUTM (2012a) Highlights of the AUTM U.S. Licensing Activity Survey: FY2011, Deerfield, IL: Association of University Technology Managers.

AUTM (2012b) Highlights of the AUTM Canadian Licensing Activity Survey: FY2011, Deerfield, IL: Association of University Technology Managers.

Breschi S., Lissoni F., Montobbio F. (2006) University patenting and scientific productivity: A quantitative study of Italian academic inventors (Cespri Working Paper no 189, November), Milano: Bocconi University.

Buenstorf G. (2009) Is commercialization good or bad for science? Individual-level evidence from the Max Planck Society. Research Policy, vol. 38, pp. 281-292.

Calderini M., Franzoni C. (2004) Is academic patenting detrimental to high quality research? An empirical analysis of the relationship between scientific careers and patent applications (Cespri Working Paper no 162, October), Milano: Bocconi University.

Carayol N. (2007) Academic incentives, research organization and patenting at a large French university. Economics of Innovation and New Technology, vol. 16, no 2, pp. 119-138.

Cervantes M., Guellec D., Kupka D. (2014) Les pratiques de valorization de la recherche publique: Un éclairage international. Realites Industrielles, Fevrier, pp. 56-61.

Chesbrough H. (2006) Open Innovation: A New Paradigm for Understanding Industrial Innovation. Open Innovation: Researching a New Paradigm (eds. H. Chesbrough, W. Vanhaverbeke, J. West), New York Oxford University Press, p. 1-12.

DIISR (2011) Australian National Survey of Research Commercialisation: 2008 and 2009, Canberra: Department of Innovation, Industry, Science and Research Australia.

DIISR (2012) Australian National Survey of Research Commercialisation: 2010 and 2011, Canberra: Department of Innovation, Industry, Science and Research Australia.

European Commission (2012) Interim Findings 2011 of the Knowledge Transfer Study 2010-2012, Bonn, Maastricht, Solothurn: European Commission.

Fabrizio K.R. (2009) Absorptive capacity and the search for innovation. Research Policy, vol. 38, no 2, pp. 255-267.

Fukugawa N. (2009) Determinants of licensing activities of local public technology centers in Japan. Technovation, vol. 29, pp. 885-892.

HEFCE (2011) Higher Education - Business and Community Interaction Survey 2009-2010, London: Higher Education Funding Council for England.

HEFCE (2012) Higher Education - Business and Community Interaction Survey 2010-2012, London: Higher Education Funding Council for England.

Hoefer R., Magill B., Santos F. (2013) Inside the mind of European academic entrepreneurs - Perceptions of ACES finalists about the process of science entrepreneurship, Science / Business Innovation Board.

Kroll H., Schiller D. (2010) Establishing an interface between public sector applied research and the Chinese enterprise sector: Preparing for 2020. Technovation, vol. 30, pp. 117-129.

Meissner D. (2012) Results and impact of national foresight studies. Futures, vol. 44, no 10, pp. 905-913.

Meissner D., Zaichenko S. (2012) Regional balance of technology transfer and innovation in transitional economy: Empirical evidence from Russia. International Journal of Transitions and Innovation Systems, vol. 2, no 1, pp. 38-71.

Meyer M. (2006) Are patenting scientists the better scholars? An exploratory comparison of inventor-authors with their noninventing peers in nano-science and technology. Research Policy, vol. 35, pp. 1646-1662.

Nayyar D. (2006) Globalisation, history and development: A tale of two centuries. Cambridge Journal of Economics, vol. 30, no 1, pp. 137-159.

OECD (2008) Open Innovation in Global Networks, Paris: OECD.

OECD (2012) OECD Science, Technology and Industry Outlook 2012, Paris: OECD. Available at: http://dx.doi.org/10.1787/ sti_outlook-2012-en, accessed 17.06.2014.

OECD (2013a) OECD Science, Technology and Industry Scoreboard 2013, Paris: OECD. Available at: http://dx.doi.org/10.1787/ sti_scoreboard-2013-en, accessed 17.06.2014.

OECD (2013b) Commercialising Public Research: New Trends and Strategies, Paris: OECD. Available at: http://dx.doi. org/10.1787/9789264193321-en, accessed 17.06.2014.

Oerlemans L., Knoben J. (2010) Configurations of knowledge transfer relations: An empirically based taxonomy and its determinants. Journal of Engineering and Technology Management, vol. 27, pp. 33-51.

Shmatko N. (2013) Graduates' Competencies for the Innovation Labour Market (HSE Working Paper Series: Science, Technology and Innovation, WP BRP 13/STI/2013), Moscow: HSE.

Spithoven A., Clarysse B., Knockaert M. (2010) Building absorptive capacity to organise inbound open innovation in traditional industries. Technovation, vol. 30, pp. 130-141.

Teece D.J. (2007) Explicating dynamic capabilities: The nature and microfounds of (sustainable) enterprise performance. Strategic Management, vol. 28, pp. 1319-1350.

Tether B., Tajar A. (2008) Beyond industry-university links: Sourcing knowledge for innovation from consultants, private research organisations and the public science-base. Research Policy, vol. 37, pp. 1079-1095.

Van Looy B., Callaert J., Debackere K. (2006) Publication and patent behavior of academic researchers: Conflicting, reinforcing or merely co-existing? Research Policy, vol. 35, pp. 596-608.

Vishnevskiy K., Karasev O., Meissner D. (2014) Integrated roadmaps and corporate Foresight as tools of innovation management: The case of Russian companies. Technolocical Forecasting and Social Change (in print). Available at: http:// dx.doi.org/10.1016/j.techfore.2014.04.011, accessed 05.07.2014. 